\title{
ARTIFICIAL NEURAL NETWORK MODEL IN PREDICTING THE QUALITY OF FRESH TOMATO GENOTYPES
}

Mladenka V. Pestorić ${ }^{1}$, Jasna S. Mastilović ${ }^{1}$, Žarko S. Kevrešan ${ }^{1}$, Lato L. Pezo ${ }^{2}$, Miona M. Belović ${ }^{* 1}$, Svetlana K. Glogovac ${ }^{3}$, Dubravka J. Škrobot ${ }^{1}$, Nebojša M. Ilić ${ }^{1}$, Adam J. Takač ${ }^{4}$

${ }^{1}$ University of Novi Sad, Institute of Food Technology, 21000 Novi Sad, Bulevar cara Lazara 1, Serbia

${ }^{2}$ University of Belgrade, Institute of General and Physical Chemistry, 11000 Belgrade, Studentski trg 12/V, Serbia

${ }^{3}$ Institute of Field and Vegetable Crops, Laboratory for Biotechnology, 21000 Novi Sad, Maksima Gorkog 30 , Serbia

${ }^{4}$ Institute of Field and Vegetable Crops, Department for Vegetable and Alternative Crops, 21000 Novi Sad, Maksima Gorkog 30, Serbia

\begin{abstract}
Sensory analysis is the best mean to precisely describe the eating quality of fresh foods. However, it is expensive and time-consuming method which cannot be used for measuring quality properties in real time. The aim of this paper was to contribute to the study of the relationship between sensory and instrumental data, and to define a proper model for predicting sensory properties of fresh tomato through the determination of the physicochemical properties. Principal Component Analysis (PCA) was applied to the experimental data to characterize and differentiate among the observed genotypes, explaining $73.52 \%$ of the total variance, using the first three principal components. Artificial neural network (ANN) model was used for the prediction of sensory properties based on the results obtained by basic chemical and instrumental determinations. The developed ANN model predicts the sensory properties with high adequacy, with the overall coefficient of determination of 0.859 .
\end{abstract}

Key words: fresh tomato quality, sensory evaluation, physicochemical properties, artificial neural network model

\section{INTRODUCTION}

Tomato (Solanum lycopersicum L.) is one of the most consumed vegetable species because of its contribution to the human nutrition. It represents a valuable source of several healthpromoting compounds due to the balanced mixture of minerals, micronutrients and antioxidants, including vitamins $\mathrm{C}$ and $\mathrm{E}$, caro- tenoids (lycopene and $\beta$-carotene), potassium, folate, tocopherol and flavonoids such as quercetin (Canene-Adams, Campbell, Zaripheh, Jeffery \& Erdman, 2005; Lenucci, Cadinu, Taurino, Piro \& Dalessandro, 2006; Slimestad \& Verheul, 2009; Pinela, Barros, Carvalho \& Ferreira, 2012). 
The quality of fruits and vegetables represents a complex of the physicochemical properties related to horticultural products and consumer perception (Kyriacou \& Rouphael, 2018). This concept encompasses all who participate in the fresh tomato chain, starting from breeders to production and consumers and includes a number of sensory and physicochemical parameters. In most cases, the sensory quality is being checked with physicochemical parameters to decide whether a product is acceptable to consumers. Although the initial consumer decision to buy is usually made on the basis of appearance, deformities and injury absence, the frequency and magnitude of subsequent purchase depend largely on their evaluation of eating quality (Corollaro et al., 2013).

Colour is considered a major attribute of tomato and relates primarily to the lycopene content (Sabio et al., 2003). Except the most common red colour, tomato fruit could be orange, yellow, pink, brown, etc. Texture is another important quality attribute of tomato, and may be considered as a final quality parameter by which the consumer decides to purchase fresh tomato (Batu, 2004). The texture of tomato is influenced by flesh firmness and skin strength. Softening during storage and retail caused by tomato ripening can be a major problem, because it may increase their susceptibility to damage. Being a climacteric fruit, ripening continues after harvest and tomato can become overripe very rapidly. This can result in quality losses and restricted shelf-life (Geeson, Browne, Maddison, Shepherd \& Guarald, 1985).

Tomato taste is attributed to various organic acids and sugar (Pinheiro, Alegria, Abreu, Gonçalves \& Silva, 2013). The relationship between the acidity and soluble solids of tomato fruit is critical to its perceived flavour. In recent years, consumers most often complained about poor flavour in tomato. They consider the new long shelf-life cultivars less tasty than the traditional ones, and they have to pay higher prices for a product with better flavour quality (Baldwin, Scott, Shewmaker \& Schuch, 2000; Ruíz et al. 2005). The lack of tomato flavour can be explained by several reasons. Traditionally, breeders have made the selection of new varieties which is characterrized by special traits such as high yield, good visual properties, slow ripening, and high re- sistance to diseases and transport, while neglecting sensorial characteristics such as aroma and taste (Maul et al., 2000; Ruíz et al., 2005). Generally, breeding of fruits and vegetables for longer shelf-life can cause undesirable pleiotropic effects on sensory attributes, such as texture and flavour (Kyriacou \& Rouphael, 2018; Rouphael, Kyriacou, Petropoulos, De Pascale \& Colla, 2018).

On one hand, the best means to precisely describe the eating quality of foods is still the sensory approach, which is applied in order to define, measure, quantify and explain what is really perceivable by human senses (Carbonell, Izquierdo, Carbonell \& Costell, 2008). On the other hand, it is expensive and often timeconsuming method. Moreover, it cannot be used for measuring quality properties in real time, an aspect particularly important for agricultural products, since their high variability requires large sampling plans. Additionally, sensory evaluation necessitates the application of destructive assessment on samples. Besides, the limitations in the availability of the sample quantity are still a serious problem for sensory evaluation.

For these reasons, instrumental measurements of physicochemical characteristics have become one of the necessities of fresh vegetable and fruit quality assessment (Oraguzie et al., 2009). Tomato quality is usually determined using a texture analyser, while soluble solids ( ${ }^{\circ}$ Brix) and titratable acidity are often measured as a replacement for sweetness and acidity. The relevance of these instrumental measurements, however, will depend on how they are able to predict sensory properties. That is because there is the essential difference between intrinsic quality characteristics of the product and the perceived sensory quality by consumers (Kyriacou \& Rouphael, 2018).

Predictive modelling is still an important field of research and a significant advance of models and unique software may be expected in the near future. The multifunctional models are often used by food scientists because they are able to quantify the interactions between two or more factors and allow the interpolation of factor combinations (Turan, Capanoglu \& Altay, 2015). Artificial neural networks (ANN) have been extensively used in the last decades for the prediction of sensory quality and acceptance of different food products, such as UHT milk (Singh, Ruhil, Jain, Patel \& Patil, 2009), 
ice cream (Bahramparvar, Salehi \& Razavi, 2014) and olive oil (Cancilla et al., 2014). ANN was successfully applied for the identification and classification of tomatoes using some characteristics obtained from computer image analysis as inputs for the model (Zaborowicz et al., 2013). On the other hand, prediction of tomato weight loss, colour and firmness changes during storage was successfully modelled using fractional conversion kinetic model (Pinheiro et al., 2013).

Bearing in mind all mentioned above, the objective of this study was to propose an effective tool for the prediction of tomato sensory properties through rapid instrumental and chemical characterisation using mathematical model, in the form of artificial neural network (ANN).

\section{MATERIALS AND METHODS}

\section{Materials}

Nine genotypes from the tomato collection of Institute of Field and Vegetable Crops (IFVC) were selected for investigation. The block diagram of the conducted research is presented in Figure 1. Description of the fresh nine tomato genotypes is presented in Figure 2. The tomato genotypes were grown during the 2011 production year in the experimental field of IFVC (Novi Sad, Serbia) at Rimski Šančevi site (N $45^{\circ} 20^{\prime}$, E $\left.19^{\circ} 51^{\prime}\right)$. The plants left prostrated and grown without support. The trial was arranged in a completely randomized block design with five replications and two rows in each. There were ten plants of each genotype per row and twenty plants per block. Plants were produced from seedlings. Inter-row spa- cing was $70 \mathrm{~cm}$, while intra-row distance was $50 \mathrm{~cm}$. From three randomly selected plants from each block a few fruits from the first inflorescence were harvested. All fruits were collected in one paper bag to form a sample. Number of harvested fruits per plant ranged from 2-4, depending of genotype. The samples were harvested at the red stage of ripeness according to USDA standards (USDA, 1991, p. 4) during one day, transported immediately to the laboratory and washed with tap water.

A part of tomato batch was homogenized using a kitchen blender (Bosch, Germany) and frozen in a refrigerator at $\sim-18{ }^{\circ} \mathrm{C}$ until chemical analyses were performed. Another part of the batch, intended for sensory evaluation, colour and texture instrumental measurements, was stored in a refrigerator at $+4{ }^{\circ} \mathrm{C}$ prior to tests which were carried out in the period of two days after harvest. Samples were taken out at least 30 minutes prior to evaluation in order to equilibrate to room temperature $\left(\sim 23{ }^{\circ} \mathrm{C}\right)$.

\section{Chemical analyses}

Total dry matter (DM) and titratable acidity (TA) were analysed according to Association Official of Analytical Chemists (AOAC, 2000), methods 925.10 and 925.53, respecttively. DM was measured by drying a sample of blended tomato at $+105{ }^{\circ} \mathrm{C}$ until stable weight was reached and the result was expressed as the percentage of fresh weight. For TA determination, $\mathrm{NaOH} 0.1 \mathrm{M}$ was used to titrate diluted and filtered blended tomato in the presence of indicator (phenolphthalein) to pale pink colour stable for $30 \mathrm{~s}$. The results were calculated as citric acid equivalents per $100 \mathrm{~g}$ of tomato.

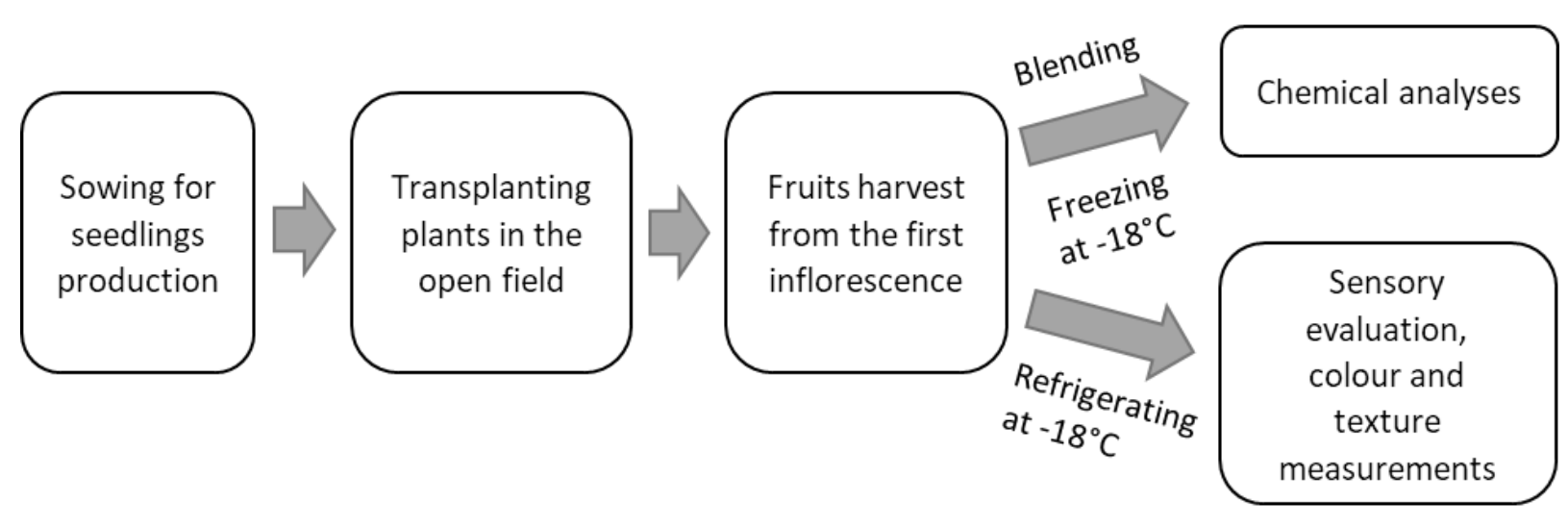

Figure 1. Block diagram of the conducted study 

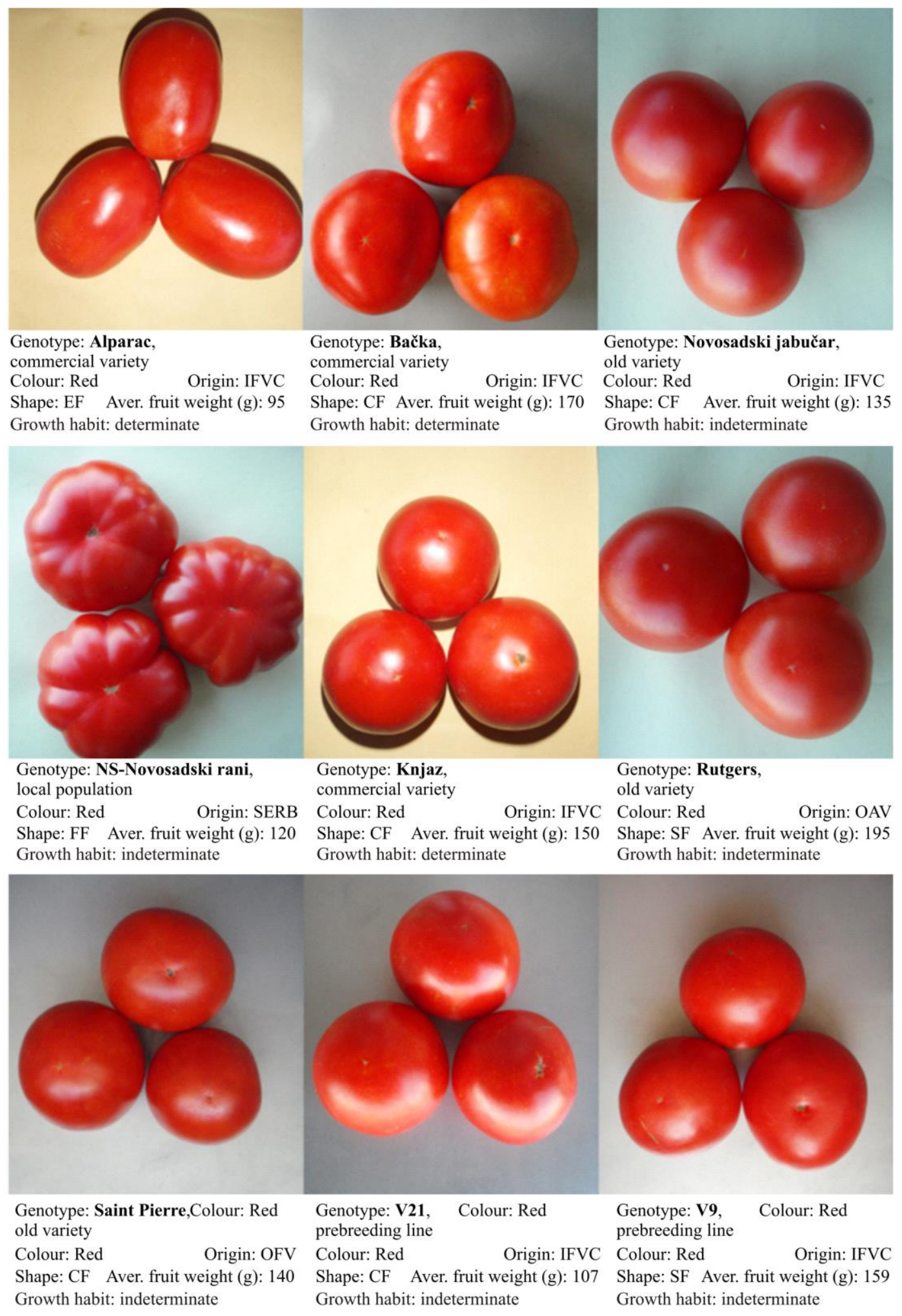

Figure 2. Description of the used tomato genotypes (IFVC - Institute for Field and Vegetable Crops; OFV - Old French variety; OAV - Old American variety; EF - Elliptic fruit; CF - Circular fruit, FF - Flattened fruit; SF slightly flattened)

Total soluble solids (TSS) and $\mathrm{pH}$ value were measured instrumentally using a table refracto- meter (ATR ST Plus, Schmidt+Haensch, Germany) and a $\mathrm{pH}$ meter with temperature probe 
(Denver Instrument, USA). All analyses were performed in triplicate.

\section{Colour and texture measurement}

Tomato colour was measured using a Minolta Chroma Meter CR-400 (Konica Minolta, Japan, Ltd.). The CIE L* (lightness), $\mathrm{a}^{*}\left(+\mathrm{a}^{*}=\right.$ redness, $-\mathrm{a}^{*}=$ greenness $), \mathrm{b}^{*}\left(+\mathrm{b}^{*}=\right.$ yellowness, $-b^{*}=$ blueness) were read applying a D65 light source and the standard observer angle at $2^{\circ}$. Five randomly chosen samples of each genotype were used for colour measurements. The colour of each sample was measured at six points: two locations between the equator and the stem; two in the equatorial region, and two between the equator and the blossom end.

Texture analysis of tomato was carried out using a TA.XTplus Texture Analyser (Stable Micro Systems, England, UK). Two different instrumental analyses were applied to measure the texture: texture profile analysis (TPA) and puncture test (PT). TPA was performed in order to measure hardness $\left(\mathrm{TPA}_{\mathrm{har}}-\right.$ maximum peak force during the first compression cycle), springiness $\left(\mathrm{TPA}_{\mathrm{spr}}-\right.$ height that the food recovers during the time that elapses between the end of the first compression and the start of the second compression), cohesiveness $\left(\mathrm{TPA}_{\mathrm{coh}}\right.$ - ratio of the positive force area during the second compression to that during the first compression), gumminess (TPA $_{\text {gum }}-$ hardness $\mathrm{x}$ cohesiveness), chewiness $\left(\mathrm{TPA}_{\mathrm{che}}-\right.$ gumminess $\mathrm{x}$ springiness), and resilience $\left(\mathrm{TPA}_{\text {res }}\right.$ - ratio of areas from the first probe reversal point to the crossing of the $\mathrm{x}$-axis and the area produced from the first compression cycle) of tomato fruit at the same time. PT was performed in order to measure tomato fruit skin strength $\left(\mathrm{P}_{\mathrm{sk}}-\right.$ maximum peak force during skin penetration) and tomato cross section hardness $\left(\mathrm{P}_{\mathrm{cs}}-\right.$ maximum peak force during pericarp penetration).

For TPA, a single fruit was placed on the heavy-duty platform (HDP/90) and compressed twice at a constant speed of $1 \mathrm{~mm} / \mathrm{s}$ to $75 \%$ strain, with a $100 \mathrm{~mm}$ diameter stainless steel cylinder $(\mathrm{P} / 100)$ and with a load cell of $30 \mathrm{~kg}$ load. For $\mathrm{P}_{\mathrm{sk}}$ determination, each tomato fruit was penetrated at the blossom end with a $2 \mathrm{~mm}$ diameter stainless steel flat cylinder probe $(\mathrm{P} / 2)$, and with a load cell of 5 $\mathrm{kg}$ load. $\mathrm{P}_{\mathrm{cs}}$ was determined in the similar manner on transversely cut tomato fruit. The instrumental settings were taken from the sample projects (TPA.PRJ) and (GRP1_P2) of the software package (Texture Exponent Software TEE32, version 6.0.6.0. Stable Micro Systems, England, UK). Five tomato fruits per batch were taken for both analyses.

\section{Sensory evaluation}

Sensory evaluation was performed using a trained panel, aged between 27 and 50 years. Ten panellists were trained with over 120 hours of general sensory descriptive training analysis with a wide range of food products. During the training session, panellists developed their ability to generate descriptors, develop terminology, correctly use the interval scales and intensity ratings. For the purpose of this research, the panellists also received further orientation and training on tomato products, to gain experience with a variety of fresh tomatoes. The highly trained panellists can be valid (ISO, 2014), and such panel have been shown externally reproducible (ISO, 2012).

The sensory descriptive terms (descriptors) and their definitions were established by panellists (Table 1). The terminology for describing the sensory descriptors of tomatoes was developed using twenty tomato products. Six 1.5 -h sessions were devoted to term generation. The terms were generated and chosen on the basis of uniqueness and objectivity, as well as on the basis of previously published research. During defining of the descriptors, the panel established the procedure for tomato sample evaluation considering the whole fruit for the evaluation of appearance and odour. The evaluation of flavour and texture was performed on transversely cut tomato samples. The training consisted 12 sessions, 4 group rating sessions and 6 individual booth sessions. During the ten generation sessions and the training session, 6 commercially processed tomatoes were presented. The appearance attributes were evaluated under white light and other attributes were evaluated under red light in the sensory lab equipped in accordance with ISO standard (ISO, 2007). The samples were served in a white porcelain saucer coded with a three-digit number at room temperature, together with plain water to clean the palate between samples. 
Table 1.

List of descriptors

\begin{tabular}{|c|c|c|}
\hline Descriptor & Abbreviation & Definition \\
\hline \multicolumn{3}{|l|}{ APPEARANCE } \\
\hline \multicolumn{3}{|l|}{ Whole fruit } \\
\hline Colour & $\mathbf{S F}_{\text {col }}$ & Intensity of fruit red colour \\
\hline Decolouration & $\mathbf{S F}_{\text {dcol }}$ & Areas coloured differently from red \\
\hline Colour uniformity & $\mathbf{S F}_{\text {cuni }}$ & Degree of red colour uniformity \\
\hline \multicolumn{3}{|l|}{ Cross-section of the fruit } \\
\hline Colour & $\mathrm{SCS}_{\mathrm{col}}$ & Intensity of fruit red colour on the cross section \\
\hline Decolouration & $\mathbf{S C S}_{\mathrm{dcol}}$ & Areas coloured differently from red on the cross section \\
\hline Colour uniformity & $\mathbf{S C S}_{\text {cuni }}$ & Degree of red colour uniformity on the cross section \\
\hline \multicolumn{3}{|l|}{ TEXTURE } \\
\hline Firmness & $\mathbf{S}_{\text {har }}$ & $\begin{array}{l}\text { The force required to cut through the tomato sample using the } \\
\text { front teeth }\end{array}$ \\
\hline Juice leakage & $\mathbf{S}_{\text {juilea }}$ & The amount of juice leaked after cutting with knife \\
\hline Skin chewiness & $\mathbf{S}_{\text {skche }}$ & $\begin{array}{l}\text { The length of time required to masticate the tomato skin to a } \\
\text { state of swallowing }\end{array}$ \\
\hline Pulp chewiness & $S_{\text {puche }}$ & $\begin{array}{l}\text { The length of time required to masticate the tomato pulp to a } \\
\text { state of swallowing }\end{array}$ \\
\hline Juiciness & $\mathbf{S}_{\text {jui }}$ & Perception of water released from the tomato during mastication \\
\hline Granularity & $\mathbf{S}_{\text {gra }}$ & $\begin{array}{l}\text { Geometrical textural attributes relating to the perception of the } \\
\text { size and shape of particles in the tomato sample }\end{array}$ \\
\hline \multicolumn{3}{|l|}{ ODOUR } \\
\hline Tomato odour & $\mathbf{S C h}_{\mathbf{o}}$ & Characteristic odour note of the whole tomato sample \\
\hline Cross-section tomato odour & $\mathbf{S C S}_{\mathbf{0}}$ & Characteristic odour note of the tomato cross-section \\
\hline \multicolumn{3}{|l|}{ FLAVOUR } \\
\hline Tomato flavour & $\mathbf{S C h}_{\mathrm{t}}$ & Flavour note characteristic for tomato \\
\hline Sweet taste & $\mathbf{S}_{\text {swe }}$ & Basic taste associated with a sucrose solution \\
\hline Sour taste & $\mathbf{S}_{\text {sou }}$ & Basic taste associated with an acid solution \\
\hline
\end{tabular}

\section{Statistical analyses}

The data were processed statistically using the software package STATISTICA 10.0 (StatSoft Inc., Tulsa, OK, USA). All determinations were made in 3 repetitions and all data were averaged, expressed by means. Analysis of variance (ANOVA) and Tukey's HSD test for comparison of sample means were used to analyse variations of the chemical analysis, colour, texture and sensory properties in tomato samples. Principal component analysis (PCA) was used to discover the possible correlations among measured parameters, and classify objects into groups.

\section{Artificial neural network (ANN) modelling}

The database for ANN was randomly divided into: training data $(80 \%)$ and testing data $(20 \%)$. Both input and output data were normalized, for better network behaviour. A multi-layer perceptron model (MLP) has been used in this study as capable of approximating nonlinear functions (Hu \& Weng, 2009). Broyden-Fletcher-Goldfarb-Shanno (BFGS) algorithm was used, as an iterative method for solving unconstrained nonlinear optimization problems in ANN modelling. Prior to calculation, input and output data were normalized (Min-Max normalization method was used in this paper) to improve the conduct of the ANN.

The training process was repeated several times in order to get the best performance of the ANN due to a high degree of variability of parameters. It was accepted that the successful training was achieved when learning and cross-validation curves (sum of squares (SOS) vs. training cycles) approached zero. Testing was carried out with the best weights stored during the training step. Coefficient of determination $\left(\mathrm{r}^{2}\right)$ and SOS were used as parameters to check the performance (i.e., the accuracy) of the obtained ANNs.

\section{RESULTS AND DISCUSSION}

\section{Analysis of variance}

The results of chemical analysis and colour determinations are shown in Table 2. Regarding chemical quality parameters, dry matter (DM), total soluble solids (TSS), and titratable acidity (TA) showed greater variation among 
tomato genotypes than $\mathrm{pH}$ values. Red tone ( $\mathrm{a}^{*}$ values) showed the greatest diversity of all measured colour parameters, followed by yellow tone ( $b^{*}$ values) and lightness $\left(\mathrm{L}^{*}\right.$ values). Variations in $a^{*}$ values could be attributed to the differences in lycopene content (Arias, Lee, Logendra \& Janes, 2000).

The results of texture analysis are shown in Table 3. The differences among the samples in terms of tomato cross section hardness $\left(\mathrm{P}_{\mathrm{cs}}\right)$, determined by puncture test, as well as hardness, gumminess and chewiness of whole tomato determined by TPA test $\left(\mathrm{TPA}_{\mathrm{har}}\right.$, $\mathrm{TPA}_{\text {gum }}, \mathrm{TPA}_{\text {che }}$ ) varied in larger extent among the tomato genotypes than other parameters.
The results of sensory evaluation of appearance attributes are shown in Table 4. Statistically significant differences were found, while the least differences were observed for tomato fruit cross-section colour $\left(\mathrm{SCS}_{\mathrm{col}}\right)$.

The sensory scores of tomato texture, odour, and taste attributes are shown in Table 5. Of all assessed textural properties, juice leakage $\left(\mathrm{S}_{\text {juilea }}\right)$ showed least variation, while granularity $\left(\mathrm{S}_{\text {gra }}\right)$ showed the greatest variation among the genotypes. Odour scores SCS $_{\mathrm{o}}$ and $\mathrm{SCh}_{\mathrm{o}}$ ) expressed lesser variability than taste scores $\left(\mathrm{SCh}_{\mathrm{t}}, \mathrm{S}_{\text {swe }}\right.$ and $\left.\mathrm{S}_{\mathrm{sou}}\right)$, with similar differentiation inside both groups of sensory descriptors.

Table 2.

Proximate chemical and colour properties of tomato samples

\begin{tabular}{lccccccc}
\hline Sample & DM & TSS & pH & TA & L $^{*}$ & $\mathbf{a}^{*}$ & $\mathbf{b}^{*}$ \\
\hline Alparac & $4.66^{\mathrm{c}}$ & $4.71^{\mathrm{b}}$ & $4.58^{\mathrm{e}}$ & $0.32^{\mathrm{b}}$ & $44.66^{\mathrm{b}}$ & $28.89^{\mathrm{d}}$ & $33.16^{\mathrm{d}}$ \\
Bačka & $3.75^{\mathrm{a}}$ & $4.51^{\mathrm{a}}$ & $4.41^{\mathrm{b}}$ & $0.28^{\mathrm{a}}$ & $44.41^{\mathrm{b}}$ & $26.39^{\mathrm{c}}$ & $32.99^{\mathrm{cd}}$ \\
Novosadski (NS) jabučar & $5.54^{\mathrm{f}}$ & $5.94^{\mathrm{e}}$ & $4.55^{\mathrm{d}}$ & $0.40^{\mathrm{d}}$ & $44.19^{\mathrm{b}}$ & $23.35^{\mathrm{a}}$ & $32.30^{\mathrm{cd}}$ \\
Novosadski (NS) rani & $5.55^{\mathrm{f}}$ & $5.03^{\mathrm{c}}$ & $4.21^{\mathrm{a}}$ & $0.48^{\mathrm{f}}$ & $39.46^{\mathrm{a}}$ & $23.78^{\mathrm{ab}}$ & $25.95^{\mathrm{a}}$ \\
Knjaz & $4.12^{\mathrm{b}}$ & $5.99^{\mathrm{e}}$ & $4.31^{\mathrm{a}}$ & $0.38^{\mathrm{cd}}$ & $42.92^{\mathrm{b}}$ & $26.28^{\mathrm{c}}$ & $30.18^{\mathrm{b}}$ \\
Rutgers & $4.48^{\mathrm{c}}$ & $6.26^{\mathrm{f}}$ & $4.54^{\mathrm{d}}$ & $0.31^{\mathrm{b}}$ & $44.38^{\mathrm{b}}$ & $28.92^{\mathrm{d}}$ & $33.07^{\mathrm{cd}}$ \\
Saint Pierre & $5.74^{\mathrm{g}}$ & $6.13^{\mathrm{e}}$ & $4.69^{\mathrm{e}}$ & $0.37^{\mathrm{c}}$ & $43.46^{\mathrm{b}}$ & $24.61^{\mathrm{b}}$ & $31.27^{\mathrm{bc}}$ \\
V21 & $5.50^{\mathrm{e}}$ & $5.44^{\mathrm{d}}$ & $4.31^{\mathrm{a}}$ & $0.39^{\mathrm{d}}$ & $40.26^{\mathrm{a}}$ & $32.38^{\mathrm{e}}$ & $26.06^{\mathrm{a}}$ \\
V9 & $5.12^{\mathrm{d}}$ & $6.23^{\mathrm{f}}$ & $4.47^{\mathrm{c}}$ & $0.44^{\mathrm{e}}$ & $43.60^{\mathrm{b}}$ & $29.28^{\mathrm{d}}$ & $31.65^{\mathrm{bcd}}$ \\
\hline
\end{tabular}

*The different superscripts within the same column $\left({ }^{a-i}\right)$ indicate significant differences of means, according to Tukey's HSD test ( $p<0.05), n=3$. DM - dry matter; TSS - Total soluble solids; TA - titratable acidity; $L^{*}$ - lightness, $a^{*}$ - redness/greenness colour component; $b^{*}$ - yellowness/blueness colour component

Table 3.

Texture parameters of tomato samples

\begin{tabular}{|c|c|c|c|c|c|c|c|c|}
\hline \multirow[t]{2}{*}{ Sample } & \multicolumn{2}{|c|}{ Puncture test } & \multicolumn{6}{|c|}{ Texture profile analysis } \\
\hline & $\mathbf{P}_{\text {sk }}$ & $\mathbf{P}_{\text {cs }}$ & TPA $_{\text {har }}$ & TPA $_{\text {spr }}$ & TPA $_{\text {coh }}$ & TPA $_{\text {gum }}$ & TPA $_{\text {che }}$ & TPA $_{\text {res }}$ \\
\hline Alparac & $489.88^{\mathrm{d}}$ & $51.26^{\mathrm{ef}}$ & $3508.25^{\mathrm{c}}$ & $0.70^{\mathrm{cd}}$ & $0.55^{\mathrm{ab}}$ & $1875.05^{\mathrm{b}}$ & $1307.07^{\mathrm{c}}$ & $0.25^{\mathrm{c}}$ \\
\hline Bačka & $606.35^{\mathrm{f}}$ & $53.24^{\mathrm{f}}$ & $4722.61^{\mathrm{e}}$ & $0.72^{\mathrm{d}}$ & $0.57^{\mathrm{c}}$ & $2670.01^{\mathrm{c}}$ & $1914.07^{\mathrm{e}}$ & $0.26^{\mathrm{e}}$ \\
\hline $\begin{array}{l}\text { Novosadski (NS) } \\
\text { jabučar }\end{array}$ & $444.13^{\mathrm{bc}}$ & $42.28^{\mathrm{d}}$ & $3935.98^{d}$ & $0.76^{\mathrm{e}}$ & $0.65^{\mathrm{d}}$ & $2543.37^{\mathrm{c}}$ & $1933.15^{\mathrm{e}}$ & $0.29^{\mathrm{e}}$ \\
\hline Novosadski (NS) rani & $486.48^{d}$ & $40.08^{\mathrm{cd}}$ & $2634.29^{\mathrm{a}}$ & $0.83^{\mathrm{f}}$ & $0.73^{\mathrm{e}}$ & $1906.39^{b}$ & $1560.36^{\mathrm{d}}$ & $0.40^{\mathrm{d}}$ \\
\hline Knjaz & $439.43^{\mathrm{a}}$ & $21.77^{\mathrm{a}}$ & $2880.60^{\mathrm{b}}$ & $0.68^{b c}$ & $0.54^{\mathrm{ab}}$ & $1530.34^{\mathrm{a}}$ & $1019.87^{b}$ & $0.24^{\mathrm{b}}$ \\
\hline Rutgers & $467.62^{\mathrm{cd}}$ & $36.19^{b}$ & $6598.99^{\mathrm{g}}$ & $0.68^{\text {bcd }}$ & $0.56^{\mathrm{bc}}$ & $3674.43^{\mathrm{e}}$ & $2506.72^{\mathrm{g}}$ & $0.25^{\mathrm{g}}$ \\
\hline Saint Pierre & $549.95^{\mathrm{e}}$ & $38.27^{\mathrm{bc}}$ & $2496.87^{\mathrm{a}}$ & $0.58^{\mathrm{a}}$ & $0.64^{\mathrm{d}}$ & $1567.11^{\mathrm{a}}$ & $933.40^{\mathrm{a}}$ & $0.30^{\mathrm{a}}$ \\
\hline V21 & $567.81^{\mathrm{e}}$ & $81.58^{\mathrm{g}}$ & $5167.41^{f}$ & $0.71^{\mathrm{cd}}$ & $0.58^{\mathrm{c}}$ & $2976.41^{\mathrm{d}}$ & $2099.66^{\mathrm{f}}$ & $0.26^{\mathrm{f}}$ \\
\hline V9 & $467.85^{\mathrm{cd}}$ & $49.16^{\mathrm{e}}$ & $7818.92^{\mathrm{h}}$ & $0.65^{\mathrm{b}}$ & $0.53^{\mathrm{a}}$ & $4102.68^{\mathrm{f}}$ & $2664.71^{\mathrm{h}}$ & $0.22^{\mathrm{h}}$ \\
\hline
\end{tabular}

*The different superscripts within the same column $\left({ }^{a-i}\right)$ indicate significant differences of means, according to Tukey's HSD test $(p<0.05), n=3 . P_{s k}$ - tomato fruit skin strength; $P_{c s}$ - tomato cross section hardness; $T P A_{\text {har }}-$ hardness; $T P A_{s p r}-$ springiness; TPA $A_{c o h}$ - cohesiveness; TPA $A_{\text {gum }}$ - gumminess; $T P A_{\text {che }}$-chewiness; $T P A_{\text {res }}$ - resilience of tomato fruit 
Table 4.

Sensory evaluation of appearance

\begin{tabular}{|c|c|c|c|c|c|c|}
\hline \multirow[b]{2}{*}{ Sample } & \multicolumn{3}{|c|}{ Whole fruit } & \multicolumn{3}{|c|}{ Cross-section of the fruit } \\
\hline & $\mathrm{SF}_{\text {col }}$ & $\mathrm{SF}_{\mathrm{dcol}}$ & $\mathrm{SF}_{\text {cuni }}$ & $\mathbf{S C S}_{\text {col }}$ & SCS $_{\text {dcol }}$ & SCS $_{\text {cuni }}$ \\
\hline Alparac & $52.92^{\mathrm{a}}$ & $24.17^{\mathrm{b}}$ & $118.33^{\mathrm{g}}$ & $53.75^{\mathrm{b}}$ & $42.50^{\mathrm{d}}$ & $77.08^{\mathrm{c}}$ \\
\hline Bačka & $54.58^{\mathrm{b}}$ & $51.25^{\mathrm{f}}$ & $68.75^{\mathrm{c}}$ & $51.67^{\mathrm{a}}$ & $70.00^{\mathrm{h}}$ & $53.75^{\mathrm{a}}$ \\
\hline Novosadski (NS) jabučar & $62.08^{f}$ & $62.92^{\mathrm{g}}$ & $55.42^{\mathrm{b}}$ & $57.50^{\mathrm{d}}$ & $42.50^{\mathrm{d}}$ & $92.50^{\mathrm{g}}$ \\
\hline Novosadski (NS) rani & $68.75^{\mathrm{h}}$ & $38.75^{\mathrm{c}}$ & $103.75^{\mathrm{f}}$ & $62.92^{\mathrm{e}}$ & $24.58^{\mathrm{b}}$ & $89.58^{\mathrm{e}}$ \\
\hline Knjaz & $56.67^{\mathrm{d}}$ & $50.00^{\mathrm{e}}$ & $80.42^{\mathrm{e}}$ & $56.25^{\mathrm{c}}$ & $22.92^{\mathrm{a}}$ & $110.42^{\mathrm{i}}$ \\
\hline Rutgers & $59.17^{\mathrm{e}}$ & $65.00^{\mathrm{h}}$ & $51.67^{\mathrm{a}}$ & $57.92^{\mathrm{d}}$ & $60.00^{\mathrm{g}}$ & $70.00^{\mathrm{b}}$ \\
\hline Saint Pierre & $55.42^{c}$ & $67.50^{\mathrm{i}}$ & $54.58^{\mathrm{ab}}$ & $55.42^{\mathrm{c}}$ & $45.00^{\mathrm{e}}$ & $97.50^{h}$ \\
\hline V21 & $82.92^{\mathrm{i}}$ & $17.92^{\mathrm{a}}$ & $126.25^{\mathrm{h}}$ & $77.50^{\mathrm{f}}$ & $29.58^{\mathrm{c}}$ & $91.67^{\mathrm{f}}$ \\
\hline V9 & $62.50^{\mathrm{g}}$ & $42.08^{\mathrm{d}}$ & $80.00^{\mathrm{d}}$ & $55.83^{\mathrm{c}}$ & $50.83^{\mathrm{f}}$ & $83.33^{\mathrm{d}}$ \\
\hline
\end{tabular}

* The different superscripts within the same column $\left({ }^{a-i}\right)$ indicate significant differences of means, according to Tukey's HSD test ( $p<0.05), n=3 . S F_{c o l}$ - Intensity of fruit red colour; $S F_{d c o l}$ - Areas coloured differently from red; $S F_{\text {cuni }}$ - Degree of red colour uniformity; $S C S_{\text {col }}$ - Intensity of fruit red colour; $S C S_{d c o l}$ - Areas coloured differently from red; $S C S_{\text {cuni }}$ - Degree of red colour uniformity

Table 5.

Sensory evaluation of texture, odour, and flavour

\begin{tabular}{|c|c|c|c|c|c|c|c|c|c|c|c|}
\hline \multirow[b]{2}{*}{ Sample } & \multicolumn{5}{|c|}{ Texture } & \multicolumn{3}{|c|}{ Odour } & \multicolumn{3}{|c|}{ Flavour } \\
\hline & $S_{\text {har }}$ & $\mathbf{S}_{\text {juilea }}$ & $\mathbf{S}_{\text {skche }}$ & $S_{\text {puche }}$ & $S_{\text {jui }}$ & $\mathbf{S}_{\text {gra }}$ & $\mathrm{SCS}_{\mathrm{o}}$ & $\mathbf{S C h}_{\mathbf{o}}$ & $\mathbf{S C h}_{\mathrm{t}}$ & $\mathbf{S}_{\text {swe }}$ & $\mathbf{S}_{\text {sou }}$ \\
\hline$c$ & $68.33^{\mathrm{d}}$ & $16.67^{\mathrm{a}}$ & $92.92^{\mathrm{b}}$ & $56.25^{\mathrm{e}}$ & $52.08^{\mathrm{a}}$ & $32.08^{\mathrm{g}}$ & $22.50^{\mathrm{b}}$ & $63.33^{\mathrm{b}}$ & $57.08^{c}$ & $42.92^{\mathrm{a}}$ & $63.75^{\mathrm{d}}$ \\
\hline Bačka & $90.00^{\mathrm{f}}$ & $17.92^{\mathrm{a}}$ & $99.58^{\mathrm{e}}$ & $77.08^{\mathrm{h}}$ & $51.25^{\mathrm{a}}$ & $60.42^{\mathrm{i}}$ & $22.50^{\mathrm{b}}$ & $58.75^{\mathrm{a}}$ & $49.17^{\mathrm{a}}$ & $43.75^{\mathrm{a}}$ & $49.17^{\mathrm{a}}$ \\
\hline jabučar & $3^{c}$ & 34.5 & & & & $6.67^{\mathrm{a}}$ & & & $97.08^{\mathrm{h}}$ & & $8^{f}$ \\
\hline Novosadski (NS) rani & $35.83^{\mathrm{a}}$ & $35.42^{\mathrm{f}}$ & $107.08^{\mathrm{h}}$ & $50.83^{\mathrm{d}}$ & $99.58^{\mathrm{e}}$ & $12.92^{\mathrm{c}}$ & $18.33^{\mathrm{a}}$ & $74.58^{\mathrm{c}}$ & $59.17^{\mathrm{d}}$ & $50.83^{\mathrm{b}}$ & $76.25^{\mathrm{h}}$ \\
\hline Knjaz & $56.67^{\mathrm{b}}$ & $22.50^{\mathrm{b}}$ & $89.17^{\mathrm{b}}$ & $32.50^{\mathrm{a}}$ & $103.33^{\mathrm{f}}$ & $10.83^{b}$ & $17.50^{\mathrm{a}}$ & $80.83^{\mathrm{e}}$ & $74.58^{\mathrm{f}}$ & $61.25^{\mathrm{c}}$ & $84.17^{\mathrm{i}}$ \\
\hline Rutgers & $67.08^{\mathrm{d}}$ & $25.42^{\mathrm{e}}$ & $95.83^{c}$ & $68.33^{\mathrm{g}}$ & $60.42^{\mathrm{b}}$ & $45.83^{\mathrm{h}}$ & $23.75^{\mathrm{c}}$ & $75.83^{\mathrm{e}}$ & $55.00^{\mathrm{b}}$ & $65.83^{\mathrm{e}}$ & $50.00^{\mathrm{b}}$ \\
\hline Saint & $69.17^{\mathrm{d}}$ & $24.58^{c}$ & $65.00^{\mathrm{a}}$ & $47.08^{b}$ & $70.42^{c}$ & $16.67^{d}$ & $21.67^{\mathrm{b}}$ & $72.92^{\mathrm{c}}$ & $67.92^{\mathrm{e}}$ & $80.00^{\mathrm{f}}$ & $56.67^{\mathrm{c}}$ \\
\hline V21 & $95.83^{\mathrm{g}}$ & $36.25^{\mathrm{g}}$ & $100.00^{\mathrm{f}}$ & $50.00^{c}$ & $80.00^{c}$ & $20.83^{\mathrm{f}}$ & $34.58^{\mathrm{e}}$ & $88.33^{\mathrm{f}}$ & $98.75^{\mathrm{i}}$ & $65.42^{d}$ & $66.25^{\mathrm{e}}$ \\
\hline V9 & $74.17^{\mathrm{e}}$ & $25.00^{\mathrm{d}}$ & $103.33^{\mathrm{g}}$ & $50.83^{\mathrm{d}}$ & $89.58^{\mathrm{d}}$ & $18.75^{\mathrm{e}}$ & $25.42^{\mathrm{d}}$ & $88.33^{\mathrm{f}}$ & $84.58^{\mathrm{g}}$ & $88.33^{\mathrm{h}}$ & $72.92^{\mathrm{g}}$ \\
\hline
\end{tabular}

*The different superscripts within the same column $\left(^{a-i}\right)$ indicate significant differences of means, according to Tukey's HSD test ( $p<0.05), n=3$. $S_{\text {har }}$ - The force required to cut through the tomato sample using the front teeth; $S_{\text {juilea }}$ - Amount of juice leaked after cutting with knife; $S_{\text {skche }}$ - The length of time required to masticate the tomato skin to a state of swallowing; $S_{\text {puche }}$ - The length of time required to masticate the tomato pulp to a state of swallowing; $S_{j u i}$ - Perception of water released from tomato during mastication; $S_{g r a}$ - Geometrical textural attribute relating to the perception of the size and shape of particle in the tomato sample; $S C h_{o}$ - Odour characteristic for whole tomato; SCS - Odour characteristic for tomato cross section; $S C h_{t}$ - Taste characteristic for tomato; $S_{\text {swe }}$ - The fundamental taste associated with a sucrose solution; $S_{\text {sou }}$ - The fundamental taste associated with acids solution

The objectively selected and determined sensory descriptors could help researchers to adequately describe the sensory quality of fresh tomatoes. Based on the results obtained, these sensory descriptors could be very successfully related to other information, such as physical and chemical data, to help researchers better understand the characteristics of various tomato products, as well as predicting the ultimate quality of tomatoes. Because of the wide range of the product characteristics caused, by cultivate, harvesting and storage conditions, some descriptors may only be appropriate for evaluating a specific set of tomato products. Thus, the number of sensory descriptors may vary accordingly and may be reduced or expended in specific studies.

\section{Principal component analysis}

Principal component analysis (PCA) was also applied to classify the different tomato genotypes (Alparac, Bačka, Novosadski jabučar, 
Novosadski rani, Knjaz, Rutgers, Saint Pierre, V21 and V9). PCA decomposed the original matrix into several products of multiplication into loading (different tomato samples) and score matrices (chemical analysis, colour, texture and sensory properties data). The PCA allowed a considerable reduction in a number of variables and the detection of structure in the relationship between measured parameters and different tomato samples. The obtained results were auto scaled prior to submission to the PCA.

The number of factors retained in the model for proper classification of the basic chemical analysis data, in original matrix into loading (different tomato samples) and score (chemical analysis, colour, texture and sensory properties data) matrices were determined by application of Kaiser and Rice's role. This criterion retains only principal components with Eigenvalues greater than 1 (Eigenvalues >1) (Kaiser \& Rice, 1974; Otto, 1999).

For the visualization of data trends and for the discriminating efficiency of the used descriptors, a scatter plot of samples using the first three principal components (PCs) from PCA of the data matrix is obtained (Figure 3). As can be seen, there was a neat separation of the tomato samples, according to 32 observed factors (chemical analysis, colour, texture and sensory properties data). The results showed that the first three principal components explained $73.52 \%$ of total variance. The first Eigenvalue was 10.75 (explaining 33.58\% of total variance), while the second and the third Eigenvalues were equal to 7.36 and 5.42 (22.99\% and $16.95 \%$ of total variance, respectively).

The colour coordinate $\mathrm{L}^{*}$ (which contributed $6.3 \%$ of the total variance, calculated based on the correlation), colour coordinate $b^{*}(6.6 \%)$, cross-section decolouration $\left(\mathrm{SCS}_{\mathrm{dcol}}\right)(7.4 \%)$, and granularity $\left(\mathrm{S}_{\mathrm{gra}}\right)(6.8 \%)$ were the most positively influential factors for the first principal component evaluation, while titratable acidity (TA) (which contributed $7.4 \%$ of the total variance, calculated based on the
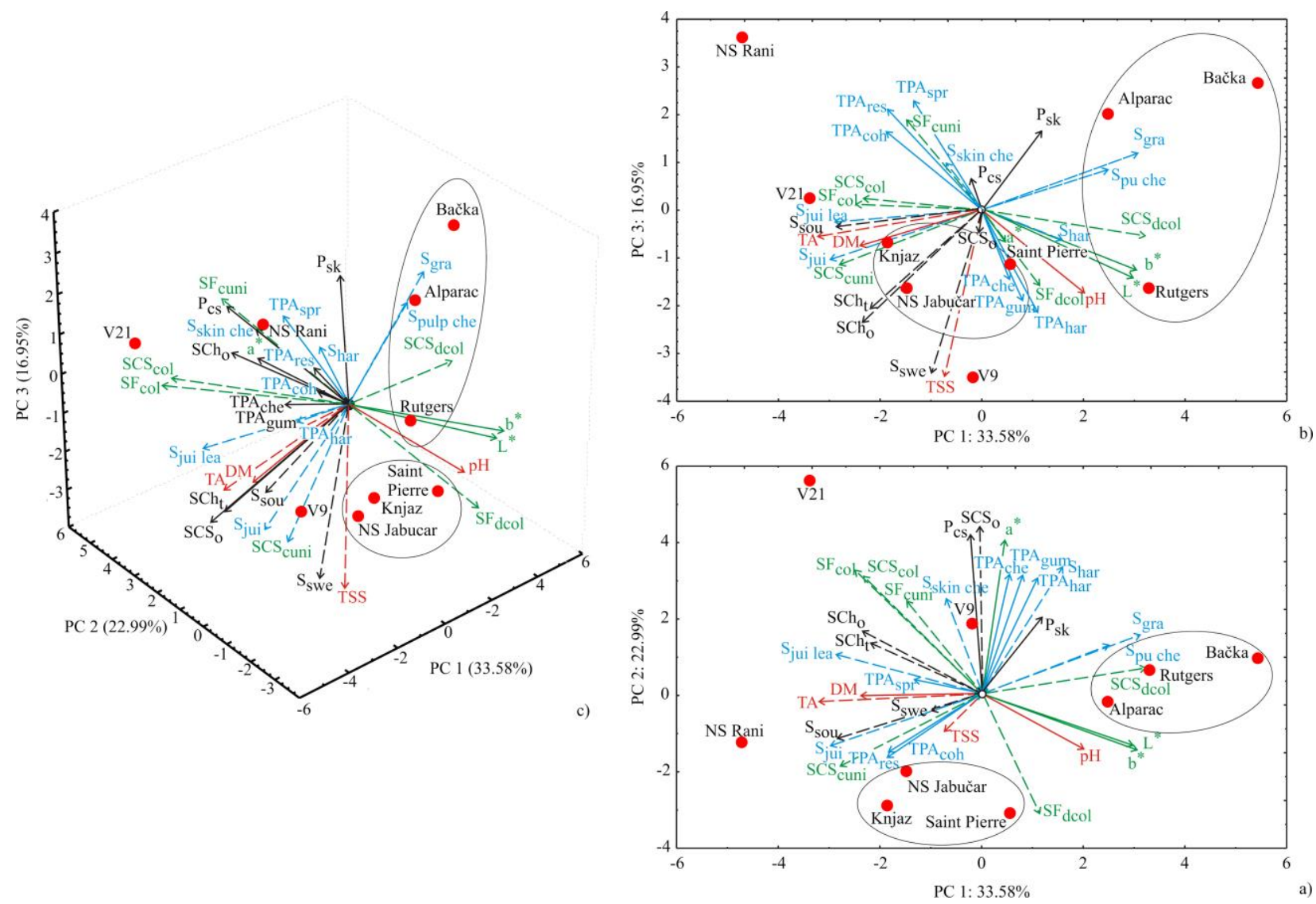

Figure 3. The PCA diagrams of investigated tomato samples and the corresponding chemical analysis, colour, texture and sensory data, a) projection in PC1-PC3 plane, b) projection in PC1-PC2 plane, c) 3D scatter plot 
correlation) and juiciness $\left(\mathrm{S}_{\mathrm{jui}}\right)(6.4 \%)$ showed the strongest negative influence on the first principal component (PC1) calculation.

The most positively influential parameters for second principal component (PC2) were colour coordinate $\mathrm{a}^{*}(9.7 \%$ of the total variance), tomato cross section hardness $\left(\mathrm{P}_{\mathrm{cs}}\right)$ determined by a puncture test $(10.5 \%)$, chewiness determined by TPA test $\left(\mathrm{TPA}_{\text {che }}\right)(6.0 \%)$, colour intensity $\left(\mathrm{SF}_{\mathrm{col}}\right)(6.2 \%)$, fruit firmness $\left(\mathrm{S}_{\mathrm{har}}\right)(6.6 \%)$ and fruit odour $\left(\mathrm{SCh}_{\mathrm{o}}\right)(11.5 \%)$.

By observing the distribution of genotypes using PCA, differences in analysed sensory and instrumental traits were noticed. Based on the distribution of genotypes between PC1 and PC2, two groups were observed. The first group consisted of genotypes Knjaz, NS jabučar and Saint Pierre while Alparac, Rutgers and Bačka belonged to the second group. Genotypes V9, V21 and NS rani were further from both groups and from each other as well, indicating the greater differences in investigated traits. The closeness of Knjaz and Saint Pierre could be explained by pedigree of Knjaz since old variety Saint Pierre is one of the two parents of variety Knjaz. Although Saint Pierre is also one of the parents of commercial variety Alparac and breeding line V9 they were at a greater distance. This could be explained by the facts that phenotype is influenced by the parents' genome, gene effects, interactions and environmental factors, in the case of quantitative traits. It can also be assumed that the genomes of the second parents of genotypes Alparac and V9 had larger contribution or more dominant effect on investigated traits.

Three genotypes outside of the formed groups had extreme values of some analysed parameters. Novosadski rani had the highest values of texture parameters springiness, cohesiveness and resilience $\left(\mathrm{TPA}_{\mathrm{spr}}, \mathrm{TPA}_{\mathrm{coh}}\right.$ and $\mathrm{TPA}_{\mathrm{res}}$ ), sensory parameter skin chewiness $\left(\mathrm{S}_{\text {skche }}\right)$ and titratable acidity (TA). It also had the lowest values for sensory parameter skin firmness $\left(\mathrm{S}_{\mathrm{har}}\right)$. Genotype V9 had highest values for texture parameters hardness, gumminess and chewiness $\left(\mathrm{TPA}_{\text {har }}, \mathrm{TPA}_{\text {gum }}\right.$ and $\left.\mathrm{TPA}_{\text {che }}\right)$, sweet taste $\left(\mathrm{S}_{\mathrm{swe}}\right)$ and characteristic tomato odour $\left(\mathrm{SCh}_{\mathrm{o}}\right)$ (genotype V9 had the highest value for this parameter along with genotype V21). Genotype V21 was se- parated because of the highest values for sensory appearance parameters $\left(\mathrm{SF}_{\text {col }}, \mathrm{SF}_{\text {cuni }}\right.$, $\mathrm{SCS}_{\mathrm{col}}$ ), sensory texture parameter $\mathrm{S}_{\mathrm{har}}$, sensory odour parameters $\left(\mathrm{SCS}_{\mathrm{o}}, \mathrm{SCh}_{\mathrm{o}}\right)$, colour parameter $\mathrm{a}^{*}$, and texture parameter $\mathrm{P}_{\mathrm{cs}}$ obtained by puncture test. Also, V21 had the lowest value for sensory evaluation parameter of appearance $\mathrm{SF}_{\mathrm{dcol}}$.

\section{ANN model}

The optimum number of the neurons in the hidden layer was chosen upon minimizing the difference between predicted ANN values and desired outputs $\left(\mathrm{SF}_{\text {col }}, \mathrm{SF}_{\text {dcol }}, \mathrm{SF}_{\text {cuni }}, \mathrm{SCS}_{\mathrm{col}}\right.$, $\mathrm{SCS}_{\text {dcol}}, \mathrm{SCS}_{\text {cuni, }}, \mathrm{S}_{\text {har }}, \mathrm{S}_{\text {juilea }}, \mathrm{S}_{\text {skche }}, \mathrm{S}_{\text {puche }}, \mathrm{S}_{\text {jui }}$, $\mathrm{S}_{\text {gra }}, \mathrm{SC}_{\mathrm{So}}, \mathrm{SCh}_{\mathrm{o}}, \mathrm{SCh}_{\mathrm{t}}, \mathrm{S}_{\mathrm{swe}}, \mathrm{S}_{\mathrm{sou}}$, according to the input variables (proximate chemical properties: DM, TSS, $\mathrm{pH}, \mathrm{TA}$; colour coordinates: $\mathrm{L}^{*}, \mathrm{a}^{*}, \mathrm{~b}^{*}$; puncture test: $\mathrm{P}_{\mathrm{sk}}, \mathrm{P}_{\mathrm{cs}}$; and texture profile analysis: $\mathrm{TPA}_{\text {har }}, \mathrm{TPAs}_{\mathrm{pr}}$, $\mathrm{TPA}_{\text {coh }}, \mathrm{TPA}_{\text {gum }}, \mathrm{TPA}_{\text {che }}$ and $\mathrm{TPA}_{\mathrm{res}}$ ), using SOS during testing as a performance indicator. Used MLP was marked according to StatSoft Statistica's notation, "MLP" followed by the number of inputs, number of neurons in the hidden layer, and the number of outputs. According to ANN performance, it was noticed that the optimal number of 12 neurons in the hidden layer for sensory variables $\left(\mathrm{SF}_{\mathrm{col}}\right.$, $\mathrm{SF}_{\text {dcol }}, \mathrm{SF}_{\text {cuni }}, \mathrm{SCS}_{\text {col }}, \mathrm{SCS}_{\text {dcol}}, \mathrm{SCS}_{\text {cuni, }}, \mathrm{S}_{\text {har }}$, $\mathrm{S}_{\text {juilea }}, \mathrm{S}_{\text {skche }}, \mathrm{S}_{\text {puche }}, \mathrm{S}_{\text {jui }}, \mathrm{S}_{\text {gra }}, \mathrm{SC}_{\mathrm{So}}, \mathrm{SCh}_{\mathrm{o}}, \mathrm{SCh}_{\mathrm{t}}$, $S_{\text {swe }}, S_{\text {sou }}$ ) calculation, 8 (network MLP 15-817) to obtain high values of $r^{2}$ (overall 0.859 ) and low values of SOS (Table 6).

The goodness of fit, between experimental measurements (proximate chemical properties: DM, TSS, pH, TA; colour coordinates: $\mathrm{L}^{*}, \mathrm{a}^{*}$, $\mathrm{b}^{*}$; puncture test: $\mathrm{P}_{\mathrm{sk}}, \mathrm{P}_{\mathrm{cs}}$; and texture profile analysis: $\mathrm{TPA}_{\text {har }}, \mathrm{TPAs}_{\mathrm{pr}}, \mathrm{TPA}_{\text {coh }}, \mathrm{TPA}_{\text {gum }}$, $\mathrm{TPA}_{\text {che }}$ and $\mathrm{TPA}_{\text {res }}$ ) and model calculated outputs, represented as ANN performance (sum of $r^{2}$ between measured and calculated outputs) and also the SOS between measured and calculated technological parameters, are shown in Table 6. The ANN model was able to predict reasonably well all process outputs for a broad range of the process variables, as seen from Table 6 . The predicted values were very close to the desired values in most cases, in terms of $r^{2}$ value, for ANN model, while SOS are of the same order of magnitude as experimental errors as reported in the literature (Basheer \& Hajmeer 2000; Pezo et al., 2013). 
Table 6.

Artificial neural network model summary (performance and errors), for training and testing cycles

\begin{tabular}{|c|c|c|c|c|c|c|c|c|}
\hline \multirow{2}{*}{$\begin{array}{c}\text { Network } \\
\text { name }\end{array}$} & \multicolumn{2}{|c|}{ Performance } & \multicolumn{2}{|c|}{ Error } & \multirow{2}{*}{$\begin{array}{c}\text { Training } \\
\text { algorithm }\end{array}$} & \multirow{2}{*}{$\begin{array}{c}\text { Error } \\
\text { function }\end{array}$} & \multirow{2}{*}{$\begin{array}{c}\text { Hidden } \\
\text { activation }\end{array}$} & \multirow{2}{*}{$\begin{array}{c}\text { Output } \\
\text { activation }\end{array}$} \\
\hline & Train. & Test & Train. & Test & & & & \\
\hline MLP $15-8-17$ & 0.859 & 0.840 & 0.277 & 0.556 & BFGS 8 & SOS & Tanh & Tanh \\
\hline
\end{tabular}

\section{CONCLUSIONS}

This investigation allowed insight in some general conclusions that enabled the comparison of nine different fresh tomato genotypes analysed. This work also aimed to improve our understanding of the instrumentally determined characteristics and sensory attributes of fresh tomato genotypes, in order to find relationships between the two measurement tools. Instrumental methods showed to be excellent tools to evaluate physicochemical characteristics of the tomato samples. The selected physicochemical methods could be used in future studies to evaluate more differently fresh tomato quality, to create models and to investigate the predictability of sensory quality.

PCA performed on the physicochemical data suggested that the fresh tomato samples were grouped in two clusters. Tomato genotypes were clearly distinguished according to 32 observed factors (chemical analysis, colour, texture and sensory properties) in three-dimensional space formed from the first three principal components, which explained $73.52 \%$ of total variance.

Artificial neural network (ANN) model was used for the prediction of sensory properties based on the results obtained by basic chemical and instrumental determinations. The developed empirical model gives a reasonable fit to experimental data. This model enables prediction of tomato sensory properties by application of rapid instrumental and chemical techniques.

The findings of this study could be applied in industrial application in manufacturer to optimize the time of maturation of fresh tomato and all quality attributes that consumer expects from this kind of product. In addition, further research, investigating how each of the physicochemical characteristics discussed in this study influences consumer acceptance of tomatoes, would give an insight into which attributes require more attention when selecting a test to predict sensory quality of tomatoes.

\section{ACKNOWLEDGEMENTS}

This work was supported by the Ministry of Education, Science and Technological Development, Republic of Serbia within the Projects No. III46001 and Project No. TR31030, and grant No. 451-03-68/2020$14 / 200222$ and 451-03-68/2020-14/200032.

\section{REFERENCES}

AOAC International (2000). Official methods of analysis $\left(17^{\text {th }}\right.$ ed.). Arlington, VA, USA: Association of Official Analytical Chemists.

Arias, R., Lee, T. C., Logendra, L., \& Janes, H. (2000). Correlation of lycopene measured by HPLC with the $\mathrm{L}^{*}, \mathrm{a}^{*}, \mathrm{~b}^{*}$ color readings of a hydroponic tomato and the relationship of maturity with color and lycopene content. Journal of Agricultural and Food Chemistry, 48, 1697-1702.

Bahramparvar, M., Salehi, F., \& Razavi, S. M. (2014). Predicting total acceptance of ice cream using artificial neural network. Journal of Food Processing and Preservation, 38(3),1080-1088.

Baldwin, E. A., Scott, J. W., Shewmaker, C. K., \& Schuch, W. (2000). Flavor trivia and tomato aroma: biochemistry and possible mechanisms for control of important aroma components. HortScience, 35, 1013-1021.

Basheer, L. A., \& Hajmeer, M. (2000). Artificial neural networks: Fundamentals, computing, design and application. Journal of Microbiological Methods, 43(1), 3-31.

Batu, A. (2004). Determination of acceptable firmness and colour values of tomatoes. Journal of Food Engineering, 61(3), 471-475.

Cancilla, J. C., Wang, S. C., Díaz-Rodríguez, P., Matute, G., Cancilla, J. D., Flynn, D., \& Torrecilla, J. S. (2014). Linking chemical parameters to sensory panel results through neural networks to distinguish olive oil quality. Journal of Agricultural and Food Chemistry, 62(44), 1066110665.

Canene-Adams, K., Campbell, J. K., Zaripheh, S., Jeffery, E. H., \& Erdman, J. W. (2005). The tomato as a functional food. Journal of Nutrition, 135, 1226-1230.

Carbonell, L., Izquierdo, L., Carbonell, I., \& Costell, E. (2008). Segmentation of food consumers according to their correlations with sensory attributes projected on preference spaces. Food Quality and Preference, 19, 71-78.

Corollaro, M. L., Endrizzi, I., Bertolini, A., Aprea, E., Demattè, M. L., Costa, F., .Biasioli, F., \& Gasperi, F. (2013). Sensory profiling of apple: Methodological aspects, cultivar characterisation and postharvest changes. Postharvest Biology and Technology, 77, 111-120. 
Geeson, J. D., Browne, K. M., Maddison, K., Shepherd, J., \& Guarald, F. (1985). Modified atmosphere packaging to extend the shelf life of tomatoes. Journal of Food Technology, 20, 339-349.

$\mathrm{Hu}$, X. \& Weng, Q. (2009). Estimating impervious surfaces from medium spatial resolution imagery using the self-organizing map and multi-layer perceptron neural networks. Remote Sensing of Environment, 113, 2089-2102.

ISO. (2012). Sensory analysis - General guidelines for the selection, training and monitoring of selected assessors and expert sensory assessors. ISO 8586. Geneva, Switzerland: International Organization for Standardization.

ISO. (2014). Methodology - Guidelines for monitoring the performance of a quantitative sensory panel. ISO 11132. Geneva, Switzerland: International Organization for Standardization.

ISO. (2007). Sensory analysis - general guidance for the design of test rooms, AMENDMENT 1. ISO 8589. Geneva, Switzerland: International Organization for Standardization.

Kaiser, H. F. \& Rice, J. (1974). Little Jiffy, Mark IV. Educational and Psychological Measurement, 34(1), 111-117.

Kyriacou, M. C., \& Rouphael, Y. (2018). Towards a new definition of quality for fresh fruits and vegetables. Scientia Horticulturae, 234, 463-469.

Lenucci, M. S., Cadinu, D., Taurino, M., Piro, G., \& Dalessandro, G. (2006). Antioxidant composition in cherry and high-pigment tomato cultivars. Journal of Agricultural and Food Chemistry, 54, 2606-2613.

Maul, F., Sargent, S. A., Sims, C. A., Baldwin, E. A., Balaban, M. O., \& Huber, D. J. (2000). Tomato flavor and aroma quality as affected by storage temperature. Journal of Food Science, 65, 12281237.

Oraguzie, N., Alspach, P., Volz, R., Whitworth, C., Ranatunga, C., Weskett, R., \& Harker, R. (2009). Postharvest assessment of fruit quality parameters in apple using both instruments and an expert panel. Postharvest Biology and Technology, 52, 279-287.

Otto, M. (1999). Chemometrics Statistics and Computer Application in Analytical Chemistry. Wiley-VCH: Weinheim, Germany.

Pezo, L. L., Curčić, B. Lj., Filipović, V. S., Nićetin, M. R., Koprivica, G. B., Mišljenović, N. M., \& Lević, Lj. B. (2013). Artificial neural network model of pork meat cubes osmotic dehydratation. Hemijska industrija, 67, 465-475.

Pinela, J., Barros, L., Carvalho, A. M., \& Ferreira, I. C. (2012). Nutritional composition and antioxidant activity of four tomato (Lycopersicon esculentum L.) farmer' varieties in North eastern Portugal homegardens. Food and Chemical Toxicology, 50, 829-834.

Pinheiro, J., Alegria, C., Abreu, M., Gonçalves, E. M., \& Silva, C. L. (2013). Kinetics of changes in the physical quality parameters of fresh tomato fruits (Solanum lycopersicum, cv. 'Zinac') during storage. Journal of Food Engineering, 114(3), 338345 .

Rouphael, Y., Kyriacou, M. C., Petropoulos, S. A., De Pascale, S., \& Colla, G. (2018). Improving vegetable quality in controlled environments. Scientia Horticulturae, 234, 275-289.

Ruiz, J. J., Alonso, A., García-Martínez, S., Valero, M., Blasco, P., \& Ruiz-Bevia, F. (2005). Quantitative analysis of flavour volatiles detects differences among closely related traditional cultivars of tomato. Journal of the Science of Food and Agriculture, 85, 54-60.

Sabio, E., Lozano, M., Montero de Espinosa, V., Mendes, R. L., Pereira, A. P., Palavra, A. F., \& Coelho, J. A. (2003). Lycopene and $\beta$-carotene extraction from tomato processing waste using supercritical $\mathrm{CO}_{2}$. Industrial \& Engineering Chemistry Research, 42, 6641-6646.

Singh, R. R. B., Ruhil, A. P., Jain, D. K., Patel, A. A., \& Patil, G. R. (2009). Prediction of sensory quality of UHT milk - a comparison of kinetic and neural network approaches. Journal of Food Engineering, 92(2), 146-151.

Slimestad, R. \& Verheul, M. (2009). Review of flavonoids and other phenolics from fruits of different tomato (Lycopersicon esculentum Mill.) cultivars. Journal of the Science of Food and Agriculture, 89, 1255-1270.

Turan, D., Capanoglu, E., \& Altay, F. (2015). Investigating the effect of roasting on functional properties of defatted hazelnut flour by response surface methodology (RSM). LWT-Food Science and Technology, 63, 758-765.

USDA. (1991). United States Standards for grades of fresh tomatoes. United States Department of Agriculture, Agricultural Marketing Service.

Zaborowicz, M., Boniecki, P., Koszela, K., Przybył, J., Mazur, R., Kujawa, S., \& Pilarski, K. (2013). Use of artificial neural networks in the identification and classification of tomatoes. In Proceedings of the Fifth International Conference on Digital Image Processing (ICDIP 2013) (Vol. 8878, p. 88782R). Beijing, China. 


\section{VEŠTAČKE NEURONSKE MREŽE ZA PREDVIĐANjE KVALITETA RAZLIČITIH GENOTIPOVA \\ PARADAJZA}

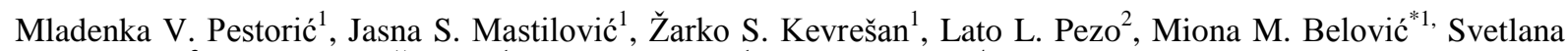
K. Glogovac ${ }^{3}$, Dubravka J. Škrobot ${ }^{1}$, Nebojša M. Ilić ${ }^{1}$, Adam J. Takač ${ }^{4}$

${ }^{1}$ Univerzitet u Novom Sadu, Naučni institut za prehrambene tehnologije u Novom Sadu, 21000 Novi Sad, Bulevar cara Lazara 1, Srbija

${ }^{2}$ Univerzitet u Beogradu, Institut za opštu i fizičku hemiju, 11000 Beograd, Studentski trg 12/V, Srbija

${ }^{3}$ Institut za ratarstvo i povrtarstvo, Laboratorija za biotehnologiju, 21000 Novi Sad, Maksima Gorkog 30, Srbija

${ }^{4}$ Institut za ratarstvo i povrtarstvo, Departman za povrtarske i alternativne biljne vrste, 21000 Novi Sad, Maksima Gorkog 30, Srbija

Sažetak: Senzorska analiza predstavlja najbolje sredstvo za precizno opisivanje kvaliteta svežih namirnica. Međutim, to je skupa i dugotrajna metoda koja se ne može koristiti za merenje pokazatelja kvaliteta u realnom vremenu. Cilj ovog rada bio je da doprinese proučavanju odnosa između podataka dobijenih primenom senzorske analize i instrumentalnih metoda i da definiše odgovarajući model za predviđanje senzorskih svojstava svežeg paradajza pomoću određivanja fizičko-hemijskih svojstava. Analiza glavnih komponenti (RSA) primenjena je na eksperimentalne podatke da bi se okarakterisali i diferencirali posmatrani genotipovi, objašnjavajući 73,52\% od ukupne varijanse, koristeći prve tri glavne komponente. Model veštačke neuronske mreže (ANN) korišćen je za predviđanje senzorskih svojstava na osnovu rezultata dobijenih osnovnim hemijskim i instrumentalnim određivanjima. Razvijeni ANN model predviđa senzorska svojstva sa visokom adekvatnošću, sa ukupnim koeficijentom determinacije od 0,859.

Ključne reči: kvalitet svežeg paradajza, senzorska ocena, fizičko-hemijska svojstva, model veštačkih neuronskih mreža

Received: 02 December 2020/Received in revised form: 02 February 2021/ Accepted: 05 February 2021

Available online: February 2021

This is an open-access article under the CC BY license (http://creativecommons.org/licenses/by/3.0). 